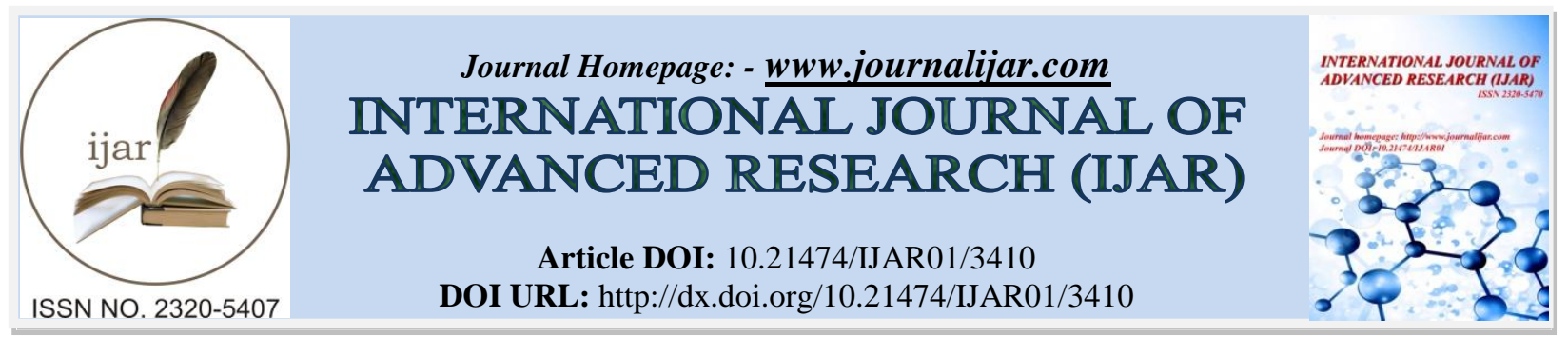

RESEARCH ARTICLE

\title{
TERRITORIAL DEVELOPMENT IN A PERIPHERAL AND DISADVANTAGED AREA. SIERRA LEONE AT A TURNING POINT.
}

Filippo Pistocchi

PhD Filippo Pistocchi, Adjunct Professor of Political and Economic Geography, University of Bologna, Italy.

\section{Manuscript Info}

Manuscript History

Received: 23 December 2016

Final Accepted: 25 January 2017

Published: February 2017
Abstract

Copy Right, IJAR, 2017,. All rights reserved.

\section{Geography And Territorial (Under)-Development. A Brief Reflection On Sierra Leone - West Africa:-}

When we talk about development we have to consider a huge number of geographical factors, that are represented by specific and complex indicators, of both the human (social, cultural, economic) and the natural sphere. These elements analyse and describe the territorial performances of the local communities, especially their mutual relationship with the environment: structures, infrastructures and info-structures, as well as socio-economic activities, political life and the expressions of culture contribute to forge a unique geographical landscape, that intersects with those of other geo-systems.

For this reason, geography, thanks to its systemic and holistic approach, helps us in the recognition of the above mentioned experiences, that are both the result and the promoters of the territorial development in this current globalized dimension.

Globalization can be a challenge, but it becomes a risk if it is not sustainably governed. Thus, competitiveness seems to be a stimulating condition for the sustainable development: it doesn't exclusively foster the economic growth, but also the social and the cultural system and the ecological integrity, i.e. conditions like "conservation and development of human capital, social gender equality; reduction at all scales of economic, social and environmental segregation; decline in quantity and intensity of flows of materials, energy, transport; promotion of participatory subsidiary models based on cooperation and partnership" (Gemmiti, 2011, p. 47). In other words, competitiveness is sustainable if a territory supports (and sustain) market competition from the local enterprises (a mix of social, environmental, economic factors), promotes innovation and the know-how (tertiary education, scientific research, culture) thanks to investments from local or international stakeholders, who become actors of the territorial development. This happens when a territory is able to produce and maintain the maximum value added, as well as cooperation for both the social and the environmental quality, and is capable to interact with other territorial systems (Prezioso, 2006; Gaddoni, Pistocchi, 2013). 
Underdeveloped regions usually don't benefit from these conditions: they still lack positive policies to enhance phenomena of social fragmentation, of informal fragile economy, of widespread illiteracy, of illegal squatter settlements, of corruption, pollution, exploitation and mistreatment, and so on.

It is then necessary to evaluate several geographical aspects, that go from history to culture, from geopolitics to economy. New or old form of slavery, poverty, and dependency on rich economies are still indicated as the main aspects of underdevelopment (Alie, 1990; Latouche, 2007; Olivier de Sardan, 1995; Pistocchi, 2009; World Bank, 2009). Moreover, environmental problems like pollution, land- and water-grabbing, deforestation and desertification, mixed with the loss of local cultures, that are consequences of underdevelopment, in turn accentuate forms of territorial poverty.

Not different is the situation in Sierra Leone, a country that globally emerged from silence few decades ago, during a terrible "civil" war (1991-2001), which was caused by a complexity of reasons: the ambition of a group to control the domestic diamond sector, the anger of the people against the Government for the underdevelopment, the interest of international actors to control the region... That conflict, however, contributed to erode the socio-economic fabric of the local communities and worsened the dramatic condition of the infrastructural and economic sectors.

Although a period of attempts to raise from darkness, Sierra Leone is still one of the Heavily Indebted Poor Countries (and it is fully qualified for debt cancellation) and one of the lowest (181 on 188) for the Human Development Index (2015). The main causes of this condition can be attributed to a complicated system of political and economic aspects at both the national and the global scale. Sierra Leone is facing a sort of paradox, that is typical of underdeveloped countries: despite its poverty (illiteracy, diseases, civil revolutions, and economic dependency on foreign investments), it is rich of resources (underground, territorial, cultural), with a quite varied and abundant quantity of vegetables and fruits. Such a frailty must be attributed both to the past (transatlantic slave trade and colonialism) and to the present globalized economy.

\section{Sierra Leone Between Local And Global Economies}

Sierra Leone is divided into four administrative regions, and more specifically in three provinces (North, with Makeni as capital city; Eastern, with Kenema as capital city, and Southern, with Bo as capital city) and the so called Western Area of Freetown, the capital.

The country is one of the 16 African states that are part of West Africa, according to the regionalization criteria adopted by the United Nations. Sierra Leone, and all the countries of the Region, that formerly belonged to the British, French and Portuguese Empires, have politically emancipated after WW II. These states, except Mauritania which came out in 2002, make up ECOWAS, namely the Economic Community Of West African States (CEDEAO in French, Communauté Economique des Etats de l'Afrique de l'Ouest), a regional economic grouping created May 28, 1975 in order to promote the integration of states in all the economic and productive fields, included infrastructures and energy, social and cultural issues. Its founding treaty was revised, integrated and reaffirmed in Cotonou (economic capital of Benin) in 1993; it asserts (art. 2) that ECOWAS is the only economic community in the region for economic integration and the attainment of the objectives of the community itself (Gamberoni, Pistocchi, 2013, pp. 230-231). Among the various initiatives, ECOWAS has been working in order to adopt a common currency, the ECO, by $2020^{1}$, notwithstanding , this appears quite difficult and problematic, primarily due to the different level of economic growth, to the diversity of the economies and to the drastic differences in size of the GDP of the countries that would adopt the ECO (e.g., Nigeria alone has a GDP of 260 billion dollars, compared to 75 billion the entire UEMOA).It is understandably a long and tortuous path, since it requires the fulfillment of a series of conditions and characteristics identified as key by WAMI (West Africa Monetary Institute). To do this, a stable and active domestic economy is necessary, to move funding and to promote projects, collaborations and globalization processes.

\footnotetext{
${ }^{1}$ The idea of adopting a single currency in West Africa by 2020 dates back to June 2007, when the Heads of State of the region's countries had signed a declaration called "Vision 2020". As in the past the Franc CFA (Franc Colonies Françaises d'Afrique) was pegged to French Franc, the ECO should be pegged to the Euro. According to the Liberian Toga McIntosh, current Vice-President of the ECOWAS Commission, the path to reach the single currency should provide for a first phase of integration between the Portuguese-speaking countries and those of the English language; then the full monetary integration between them and the French-speaking area UEMOA (Union Economique et Monétaire Ouest Africaine), in which the CFA Franc is already in force (http://atlasweb.it/2013/09/12/africa-occidentale-entro-il-2020-arriva-leco-la-nuova-moneta-unica-579.html).
} 
India, Brazil but especially China are the new economic superpowers that are responsible of a quite controversial economic development: the combination «infrastructure in exchange for resources» sums up this sort of relationship. China, which is experiencing a fast process of economic growth and that it is lacking raw materials (especially energy) is "forced" to turn to Africa and buy or trade its resources by building in exchange large infrastructures (roads, hydroelectric dams, airports).

These are impressive works, which on the one hand improve the spatial performance of entire regions, and contribute to raise the quality of life of entire human groups: this could be an opportunity for the local development, even in a scenario of South-South partnership ${ }^{2}$; on the other hand, however, the local governments and the local communities lose any kind of control on these vast areas. Although in the short term these large investments and the impressive works by Chinese companies (there are 30 currently active in the territory of Sierra Leone) produce some benefits, in the long term the major Chinese projects do not contribute to build the foundations for a long-lasting, solid and resilient development, since it does not protect land resources, and do not promote local expertise, which, when they are not replaced by Chinese labor, are exploited in a working condition of subordination. That's why someone talks about «China's Silent Storm in Sierra Leone» (Datzberger, 2013).

This is what matters: «[...] looking at China as an infrastructural developer for Sierra Leone, they have made significant progress on the Freetown urban landscape from the multi-use national stadium to Youyi building (ministerial complex). Over the past decades; they have built bridges, power transmissions, a dam and some roads. More recently, the Chinese contractors finished constructing a new foreign ministry building, additional offices for parliament and the 100-bed China Sierra Leone Friendship Hospital at Jui, outside of Freetown. And President Ernest Koroma, early in July, 2013 signed a deal with Chinese Railway International Company to build a new airport and a railway amounting in the total of $\$ 8$ billion. Thus, China has significantly supported some level of economic growth for Sierra Leone» (http://standardtimespress.org).

But the newspaper article "The growing interest of China in Sierra Leone", 27th August, 2016 (http://standardtimespress.org), complaint that China continues to ignore the level of corruption in this country and in particular in the high ministerial and government troops. This for a number of reasons such as opportunism and practicality: China, for its projects in Sierra Leone, use Chinese workers instead of local workforce and seems not interested in the internal political dynamics. Unfortunately, this laissez-faire attitude seems to worsen the fragile socio-political system, because it breaks down the sense of belonging and the civic participation of the locals, who better appreciate those new, quick, and efficient infrastructures.

\section{Political power and the Shadow-State model}

This weakness is largely dependent on the so called «shadow-state», originated from a two-hundred-years period, when these territories have experienced a rapid political transition, from pre-colonial state (made of noble lineages and of a society divided into strict social classes) to colonial (dual, made of white settlers and blacks subjects) to the post-colonial era (the current one, of independent but non self-sufficient states). The colonial state completely reshaped societies, and transformed the form of aggregation and organization (law and economics), repositioning individuals or entire ethnic groups in new geographic spaces (provinces, administrative districts, municipalities) that had little or nothing to do with places and traditional territories (kingdoms, ethnicities). They thus created the political dichotomies and conceptual dyscrasia (common law vs. civil law, urban world vs. rural world, the center vs. periphery, leadership vs. mass of citizens, rich vs. poor) that form the basis of the serious problems related to underdevelopment. Such conditions cause on the one hand fragmentation and separation, on the other the contradictions of a democratic society (Turco, 2004), made of territorial systems in which the gap between town and country is still very strong, and in which the same urbanization is characterized by interstitial spaces and overwhelming informal economies (Gamberoni, Pistocchi, 2013, p. 97).

Sierra Leone is still struggling to emancipate. In the past, it «was the first centre of modern civilization in West Africa» (HIGSON 1961, p. 191). But at the dawn of the independence processes other countries like Nigeria and Ghana were beginning to take on a leading role in the regional economy. So, Sierra Leone needed «improved

${ }^{2}$ This is legitimated by the FOCAC, the Forum On China and Africa Cooperation, established in 2000, which provides for bilateral economic agreements between the Beijing government and each partner African state. However, it seems to be an unequal exchange. 
services (especially of education in the Protectorate ${ }^{[3]}$ ) and these cost money. This can be raised by loans from abroad or by increased production within the country. Loans can only be a temporary solution: increased production will require the combined efforts of the whole population. The national income could, however, be added to in the near future by the: 1) regulation of the diamond industry and prevention of illicit mining and selling of the stones; 2) rapid development of swamp rice production; 3 ) increase of iron ore and other mineral production; 4) development of plantation cultivation of bananas, citrus fruits and pineapples; 5) more scientific cultivation of oil palm, to ensure greater output and better quality. The economic problem of Sierra Leone is a serious one and must be solved as soon as possible in order to allow for the orderly and natural development of self-government» (Higson 1961, p. 191).

\section{A Contradictory Development}

The following tables (table 1, 2, 4, 4) summarize some of the major geographical performances about Sierra Leone from the World Bank Development Index 2016.

Table 1: Demography of Sierra Leone

\begin{tabular}{|l|l|l|l|l|l|}
\hline Population & $\begin{array}{l}\text { Population } \\
\text { density }\end{array}$ & $\begin{array}{l}\text { Urban } \\
\text { population }\end{array}$ & $\begin{array}{l}\text { Population of the } \\
\text { Capital City } \\
\text { (census 2014) }\end{array}$ & $\begin{array}{l}\text { Capital } \\
\text { population } \\
\text { density }\end{array}$ & $\begin{array}{l}\text { Net migration } \\
\mathbf{2 0 1 0}-2015\end{array}$ \\
\hline $6,300,000$ & $\begin{array}{l}87 \text { people per } \\
\text { sq. } \mathrm{km}\end{array}$ & $40 \%$ & 951,000 & $\begin{array}{l}2,664 \text { people per } \\
\text { sq. } \mathrm{km}\end{array}$ & $-21,000$ \\
\hline
\end{tabular}

Table 2: Socio-economic Aspects: Growth, Employment, Poverty

\begin{tabular}{|l|l|l|l|l|l|l|l|}
\hline $\begin{array}{l}\text { GDP } \\
\text { per } \\
\text { capita }\end{array}$ & $\begin{array}{l}\text { GDP per capita } \\
\text { growth rate }\end{array}$ & \multicolumn{3}{|c|}{ Annual GDP growth rate } & $\begin{array}{l}\text { People under the poverty } \\
\text { line } \\
(\mathbf{2 0 1 1})\end{array}$ & $\begin{array}{l}\text { Foreign Direct } \\
\text { Investment }\end{array}$ \\
\cline { 3 - 8 } & & $\begin{array}{l}\mathbf{1 9 9 9 -} \\
\mathbf{2 0 0 0}\end{array}$ & $\begin{array}{l}\mathbf{2 0 0 0 -} \\
\mathbf{2 0 0 9}\end{array}$ & $\begin{array}{l}\mathbf{2 0 0 9 -} \\
\mathbf{2 0 1 4}\end{array}$ & $\begin{array}{l}\text { Less than } \\
\mathbf{3 , 1} \text { a day }\end{array}$ & $\begin{array}{l}\text { Less than } \\
\mathbf{1 , 9} \$ \text { a day }\end{array}$ & \\
\hline $700 \$$ & $+2.3 \%$ & $-3 \%$ & $+7.2 \%$ & $+11 \%$ & $80 \%$ & $52.8 \%$ & 690 million $\$$ \\
\hline
\end{tabular}

Table. 3: Society and Quality of Life

\begin{tabular}{|c|c|c|c|c|c|c|}
\hline \multirow{2}{*}{$\begin{array}{l}\text { Child } \\
\text { mortality } \\
(0-5) \\
(2015) \\
\end{array}$} & \multirow{2}{*}{$\begin{array}{l}\text { Maternal } \\
\text { mortality } \\
\text { (2015) }\end{array}$} & \multirow[t]{2}{*}{$\begin{array}{l}\text { Fertility (15-19) } \\
(\mathbf{2 0 1 4})\end{array}$} & \multirow{2}{*}{$\begin{array}{l}\text { HIV Adults } \\
(15-49) \\
\text { infected } \\
(2014)\end{array}$} & \multirow{2}{*}{$\begin{array}{l}\text { Youth literacy } \\
\text { rate }(15-24) \\
(2005-2014)\end{array}$} & \multicolumn{2}{|c|}{$\begin{array}{l}\text { Digital divide } \\
\text { (2014) }\end{array}$} \\
\hline & & & & & $\begin{array}{l}\text { New mobile } \\
\text { subscriptions }\end{array}$ & $\begin{array}{l}\text { Private use } \\
\text { of Internet }\end{array}$ \\
\hline $120 \%$ & $13.6 \%$ & $120 \%$ & $1.4 \%$ & $64 \%$ & $+77 \%$ & $2 \%$ \\
\hline
\end{tabular}

Table 4: Environment and pollution

\begin{tabular}{|l|l|l|l|l|}
\hline $\begin{array}{l}\text { Deforestation } \\
\mathbf{2 0 0 0}-(\mathbf{2 0 1 5})\end{array}$ & $\begin{array}{l}\text { Protected } \\
\text { areas } \\
(\mathbf{2 0 1 4})\end{array}$ & $\begin{array}{l}\text { Fresh water } \text { per } \\
\text { capita } \\
(\mathbf{2 0 1 4})\end{array}$ & $\begin{array}{l}\text { People with access to good } \\
\text { sanitation facilities }\end{array}$ & $\begin{array}{l}\mathbf{C O}_{2} \text { emissions } \\
(\mathbf{2 0 1 1})\end{array}$ \\
\hline$-0.28 \%$ & $3.8 \%$ & $25,334 \mathrm{~m}^{3}$ & $63 \%$ & 0.9 millions of tons \\
\hline
\end{tabular}

Table 1 shows the total population of Freetown, the capital, and its population density (2,664 inhabitants / km against the country's average 87). This of most of the territories in rapid process of growth: the urban gigantism and the primacy of the capital city or a few other urban settlements than the rest of the territory. Big-primatial cities in underdeveloped or developing countries are still very controversial, because the relationship between the global and the local is negative. Often, unscrupulous businessmen choose the chaotic capital city of underdevelopment as a free territory, to hide their illegal activities. For these reasons, urbanization needs responses for the impacts it produces on the territory, the environment, the society and its economy. In particular, the main environmental problems are particularly concerned with water and energy waste, pollution and the resulting social ills: economic poverty and

${ }^{3}$ That book was edited in 1961, the same year of the Independence. "Protectorate" meant the inner areas: the author underlined the urgency to enhance education in the "peripheral" areas, namely those where people were still mainly living mainly with the primary sector subsistence activities. 
social marginalization slow down and discourage political intervention and planning aimed at making sustainable the progressive urban growth.

However, this condition is not only typical of the poorest areas of the earth: cities such as Tokyo, New York, Paris, London, for example, can in some way be defined «primatial». But with one major difference: their level of urbanization determines the strengthening of the economic structure also of the suburbs, and urbanization enhances the entire territory; on the contrary, in underdeveloped regions or emerging economies, urbanization does not necessarily correspond to a better quality of life.

Freetown attracts a lot of people from the countryside and suburbs: it provides some excellent services (headquarters of banks, multinational corporations), but still lacks some basic services to citizens and cannot provide services for the suburbs and the surrounding countryside.

Surely, the country is in strong economic growth (tab. 2). Even EPA, the Environmental Protection Agency, confirms the positive development of Sierra Leone's economic performance, growth which, however, has taken place at a much lower rate than that of other countries in sub-Saharan Africa. «The poverty headcount has declined from 66.4 percent in 2003 to 52.9 percent in 2011 . The overall reduction was led by strong growth in rural areas, where poverty declined from 78.7 percent in 2003 to 66.1 percent in 2011, yet this figure was overall still higher than urban poverty. Urban poverty declined from 46.9 percent in 2003 to 31.2 percent in 2011 . This decline was despite an increase from 13.6 percent to 20.7 percent in the capital, Freetown. District level poverty analysis showed that by 2011 most districts had converged to poverty levels between 50 and 60 percent, with the exceptions being Freetown at 20.7 percent and levels above 70 percent in Moyamba and Tonkolili. Underlying this poverty reduction was an annualized 1.6 percent per capita increase in real household expenditure from 2003 to 2011» (EPA, 2014, p. 12).

Although the growth rate of per capita GDP is positive $(+2.3 \%)$, this process is still unable to eradicate widespread and extreme poverty that emerges from the data for the percentage of people living under the absolute poverty line (52.8\% of the population) in 2011.

What emerges from the economic indicators is also reflected in the social conditions (tab. 3): the gap between rich and poor is still wide, as well as between the services provided and the people's needs. Even health data are not entirely comforting, especially those related to maternity-care and child-care. In particular, child mortality $0-5$ is dramatic: it means that health facilities and medicines, as well as physical and economic accessibility to medical care are not guaranteed.

Talking about environment (tab. 4), a reflection on wrong policies is required: although availability of fresh water is medium-high $\left(25,334 \mathrm{~m}^{3}\right.$ compared to the world average of 5,925), sewage and water treatment systems are still poor, justifying the high percentage of some of the more frequent diseases (diarrhea, fever, cholera, malaria) due to the assumption or the presence of dirty or contaminated water.

Uncontrolled deforestation is decreasing, but an ecological approach for the preservation and the institution of protected areas don't seem to be a governmental priority. Indeed, in a vision of development and sustainability, it could be a successful policy for both the environment and the promotion of tourism that, in turn, could support the socio-economic sector. The level of dioxide emissions is very low. This is attributable not to policies ${ }^{4}$ to prevent pollution and protect the environment, but, again, to an economic and industrial system underdeveloped.

This is a challenge: the country is constantly exposed to risks of instability and periodic events that slow down or block the path toward a stable development. For example, in the past two years Ebola caused many deaths, as well as socio-economic problems connected with farming and environmental health: the affected areas were quarantined and rural areas were left abandoned and remained uncultivated for months; children and the youths didn't go to school; any other activity was suspended.

\footnotetext{
${ }^{4}$ In this current global scenario, the country has been trying to adapt its policies to the Millennium Goals.
} 


\section{Ebola And Intervention Policies: Victory Or Defeat?}

Ebola is an insidious disease because it is of easy infection and difficult to cure, which put a strain on not only some regions of West Africa (Guinea, Sierra Leone, Liberia), but the whole humanity: the disarming impotence in front of the spread of such a disease (without being able to stop it promptly) causes amazement, dismay, sense of failure.

Africa is living a strong and fast economic growth. However, the gap between wealth (little and poorly distributed) and poverty (and very widespread) is still marked.

For these reasons, the challenge of solving a health problem opens complex scenarios, since it is part of a broader field of study, which inevitably also involves the economic, political and social sphere. The disease in Africa is closely linked to the complex food- cultural- social- and economic- system.

A very low human development, a fragile health system and a large internal migration led to the spread of Ebola and to the collapse of the country. Besides these reasons we must not forget the archaic traditional rites around death and the dead, during which the corpse is exposed to people.

It is not for mere irony that Ebola has spread in the same areas affected by the drama of the blood-diamonds war and the child-soldiers. Those are vast border areas, passageways from one State to another, poor of institutional barriers and delimited by the so called «porous» borders: they divide two States, but only one ethnic region, that is inhabited by the same people. That ethnic group was divided during the colonial and post-colonial power, and suffered a sort of geographic diaspora. So, they now nourish a strong sense of belonging and live in continuous contact, ignoring the constraints imposed by international geopolitics. The state is unable to ensure an effective and active control: illegal trade, smugglers, terrorists, and diseases are not stuck by borders. For example, «while Nigeria's border problem is related to this colonial history, its porosity has been exacerbated by the failure of succeeding governments to properly administer these borders. As Okumu noted, «the high level of insecurity on African borders is largely due to the way they are administered and managed, and less to do with how colonialists drew them. In this respect, Nigerian borders are known for the limited presence of security and law enforcement officials. The few that are deployed are poorly trained, work with inadequate and obsolete equipment, and sometimes poorly remunerated. In addition, most border communities have for long been neglected by the government, making it difficult for government to leverage on their position to curtail illicit crossborder activities» (Onuoha, 2013, p. 4).

The most affected districts were those at the border with Liberia (Kailahum and, by geographical proximity, Kenema) and Guinea (Bombali and, by geographical proximity, Port Loko): those are the districts through which the main interregional roads pass from one country to another. Moreover, Makeni (Bombali District) is the capital of the whole Northern Region, and Kenema (Kenema District) is the capital of the Eastern Region, therefore, they are the most populated urban areas of those regions.

In the absence of adequate equipment and sanitary facilities, it was difficult to make a prompt diagnosis to prepare an effective contrast therapy. The symptoms of this disease, in fact, are generally high fever (more than $38^{\circ} \mathrm{C}$ ), headache, muscle aches, vomit, diarrhea, abdominal pain, bleeding, that are very common to many other diseases (malaria, yellow fever...). Therefore, at the beginning of the outbreak of Ebola, people were not alarmed and behaved without precautions: many civilians helped doctors and nurses in hospitals and took care of their loved ones and so they have been infected too.

To avoid infection, while waiting for an international systematic intervention, it was made an ambiguous and controversial choice, the "quarantine": whole areas of Sierra Leone, in particular the rural and less accessible, have been isolated, with the prohibition for the inhabitants to leave their houses, to go into the fields and to support each other.

The result was that entire plantations were abandoned, the countryside was invaded by wild-nature, and all the rural economy was destroyed: these safety and prevention strategies have caused hunger and malnutrition, have weakened the body and the immune system of people and have favored the emergence of other diseases.

The prices of everyday products such as rice, potatoes, and oil have increased by $30 \%$ (tab. 5). This has led to a surge in inflation, that grew up in a few days from 6.39 at $7.8 \%$. 
Table. 5: Ebola impact on the production and sale of the main agricultural products and foodstuffs in Liberia, Sierra Leone and Guinea (FAOSTAT 2015, p. 4).

\begin{tabular}{|c|c|c|c|c|c|c|}
\hline Country & Rice & & Cassava & & Corn & \\
\hline & $\begin{array}{l}\text { Reduction of } \\
\text { production } \\
\text { (tons) }\end{array}$ & $\begin{array}{l}\text { Loss of } \\
\text { production } \\
\text { value } \\
\text { USA) }\end{array}$ & $\begin{array}{l}\text { Reduction of } \\
\text { production } \\
\text { (tons) }\end{array}$ & $\begin{array}{l}\text { Loss of } \\
\text { production } \\
\text { value } \\
\text { USA) }\end{array}$ & $\begin{array}{l}\text { Reduction of } \\
\text { production } \\
\text { (tons) }\end{array}$ & $\begin{array}{l}\text { Loss } \\
\text { production } \\
\text { value } \\
\text { USA) }\end{array}$ \\
\hline Liberia & 24,000 & $10,000,000$ & 19,000 & $2,000,000$ & - & - \\
\hline Sierra leone & 100,000 & $43,000,000$ & 37,000 & $4,000,000$ & 2,000 & 300,000 \\
\hline Guinea & 55,000 & $23,000,000$ & 4,000 & 400,000 & 24,000 & $4,000,000$ \\
\hline
\end{tabular}

Many foreign companies, such as China Union, the Vale and the Marampa, have drawn all their employees at home. These sudden closures led to the collapse of all commercial transactions and, consequently, the unemployment of many workers who worked in sectors linked with these big foreign companies.

The growth rate of GDP (2001-2014) was -29.67\%. This data must precisely be imputed to the fact that for at least 169 days, half of the entire population of the country has lived without money. Schools and universities were closed: teachers and administrative staff did not receive salary, while students have lost a whole year of training and have delayed a year their entry into the world of work.

Ultimately this phenomenon, which has severely affected the socio-economic sector, has also damaged the tourism industry: data show that the number of tourists in a few months dropped by $50 \%$ or even $60 \%$.

On $7^{\text {th }}$ November 2015, Sierra Leone was declared Ebola-free, since, in accordance with safety procedures, no negative test for the Ebola virus was recorded in the previous 42 days. The population started to return to their daily lives and to their work activities. Yet, in late January 2016, new infection cases alerted the community. It took month to definitely proclaim Sierra Leone Ebola-free.

For now it seems that Ebola has claimed nearly 4,000 deaths in Sierra Leone, nearly 5,000 in Liberia and more than 2,500 in Guinea.

\section{Final Remarks}

Sierra Leone is not yet a State democratically made; scholars even define it a failed state. A young country like Sierra Leone needs a strong political and administrative system, able to guarantee cohesion, in safeguarding and promoting the complex socio-cultural structure.

The cultural, political, economic identity of Sierra Leone, like that of any other territory, does not end within its territorial unit; on the contrary, it can be understood through a global vision of its political and economic dynamics.

\section{References}

1. Acemoglu D., Robinson J. A., Why Nations Fail. The origins of power, prosperity, and poverty, New York, Crown Business, 2012

2. AdésínÀ J. O., Graham Y., Olukoshi A. (eds.), Africa and Development. Challenges in the New Millennium, London, Zed Books, 2006.

3. AFREA, Wood-Based Biomass Energy Development for Sub-Saharan Africa, The International Bank for Reconstruction and Development, 2011

4. AliE J. A. D., A New History of Sierra Leone, Londra, MacMillan, 1990.

5. Ashley C., RoE D., Goodwin H., Pro-Poor Tourism Strategies: Making Tourism Work for the Poor. A review of experience, London, Overseas Development Institute, 2001.

6. Auregan X., “ "Communauté » libanaise en Afrique de l'Ouest”, in La revue géopolitique, Diploweb.com, 2012

7. BARBOUR K. M., “Un'analisi geografica dei confini politici dell'Africa intertropicale”, in L. SCARAFFIA (ed.), Demografia e società in Africa negli anni della decolonizzazione, Milano, Franco Angeli, 1979, pp. $258-275$. 
8. Blundo G., Olivier De SARDAN J.-P., "La corruption au quotidien. Sémiologie populaire de la corruption”, in Politique Africaine, 2002, pp. 98-114.

9. Brautigam D., "Land Rights and Agricultural Development in West Africa: A Case Study of Two Chinese Project", in The Journal of Developing Areas, n. 27, 1992, pp. 21-32.

10. BRUNEL S., "Sierra Leone: les difficultés du développement dans une société en armes", in Bulletin Association de Géographes Français, vol. 79, n. 2, 2002, pp. 237-250.

11. Calchi Novati G., "At the Sources of the Contemporary African State: Late XIX Century Polity and Society in Monrovia and Freetown", in The Journal of Pan African Studies, vol. 1, n. 8, 2007, pp. 52-76.

12. DATZBERgER S., "China's Silent Storm in Sierra Leone", in South African Institute of International Affairs, Global Powers and Africa Programme, 2013

13. DAVIES V. A. B., "Sierra Leone: Ironic Tragedy", in Journal of African Economies, vol. 9, n. 3, 2000, pp. 349369.

14. DFID, Building the State and Securing the Peace, Emerging Policy Paper, DFID, London, 2009

15. DRew E., RAmSBotham A., Consolidating peace. Liberia and Sierra Leone, ACCORD, n. 23, 2012

16. ECOWAS, Regional Agricultural Policy for West Africa: ECOWAP. Make agriculture the lever of regional integration, 2008 .

17. FAO, Sierra Leone - BEFS Country Brief, Bioenergy and Food Security Projects, 2013

18. GAmberoni E., Pistocchi F., Africa occidentale. Ritratto di un 'Africa che cambia, Bologna, Pàtron, 2013

19. Gemmiti R., "Territorial Competitiveness in Sustainability. The Interpretation at the Base of the Research", in Prezioso M. (ed.), Competitiveness in Sustainability, Bologna, Patron, 2011

20. Gerosa V., "Pro-Poor Strategies in Africa", Meeting on Tourism: A Viable Option for Pro-Poor Growth in Africa?, Kampala 23-24 June 2003.

21. Gordon A.A., GoRdOn D.L., Understanding Contemporary Africa, Boulder, Lynne Rienner Publishers, 2007.

22. HARRIS D., "Post-Conflict Elections or Post-Elections Conflict: Sierra Leone 2002 and Patterns of Voting in Sub-Saharan Africa", in Cadernos de Estudos Africanos, n. 5/6, 2003, pp. 39-49.

23. Higson F. G., A Certificate Geography of West Africa, London, Longmans, 1961.

24. HIRSCH J. L., Sierra Leone. Diamonds and the Struggle for Democracy, United States of America, International Peace Academy, 2001.

25. HOFFMAN D., "The civilian target in Sierra Leone and Liberia: political power, military strategy, and humanitarian intervention", in African Affairs, vol. 103, 2004, pp. 211-226

26. Jarrett A. A., "Some Aspects of the Urban Geography of Freetown, Sierra Leone", in Geographical Review, vol. 46, n. 3, 1956, pp. 334-354.

27. Johnson E., Blood Diamonds: The Conflict in Sierra Leone, 2002, http://web.stanford.edu/class/e297a/Conflict\%20in\%20Sierra\%20Leone.htm

28. KAYOdE F., "Governing Insecurity in Post-Conflict States: The Case of Sierra Leone and Liberia", in BRYDEN A., HANGGI H. (eds.), Reform and Reconstruction of the Security Sector, Munster, Verlag e Dcaf, 2004, pp. 179205.

29. ODERMATt J., "New Wars' and the International/Non-international Armed Conflict Dichotomy", in International Institute of Higher Studies in Criminal Sciences, www.isisc.org, 2009 (PDF)

30. Odermatt J., "Between Law and Reality: 'New Wars' and Internationalised Armed Conflict", in Amsterdam Law Forum, VU University Amsterdam, vol. 5, n. 3, 2013, pp. 19-32

31. OECD, The State's Legitimacy in Fragile Situations - Unpacking Complexity, Paris, 2010

32. Olivier De SARDAN J.P., "L'économie morale de la corruption en Afrique", in Politique Africaine, n. 83, 2001, pp. 97-116.

33. OlVIER De SARDAN J.P., Antropologie et développement: essai en socio-anthropologie du changement social, Paris, Apad Karthala, 1995.

34. ONuOHA F. C., "Porous Borders and Boko Haram's Arms Smuggling Operations in Nigeria", in Report Al Jazeera Center for Studies, September, 2013

35. PaAsi A., "Territory", in Agnew J., Mitchell K., Toal G. (eds.), A Companion to Political Geography, Oxford, Blackwell, 2003, pp. 109-122.

36. Pistocchi F., "Slavery Heritage for the Socio-Economic Development in Sierra Leone", in Rivista Geografica Italiana, vol. 118 , n. 3, 2010, pp. 597-624

37. PISTOCCHI F., "Territorio, identità e potere in Sierra Leone, dallo Slave Trade ai Blood Diamonds", in Rivista geografica italiana, vol. 116, n. 1, 2009, pp. 47-82.

38. POUTIER R., "Géopolitiques africaines", in Association de Géographes Français, vol. 79, n. 2, 2002, pp. 131133. 
39. Prezioso M., "La dimensione territoriale della strategia Lisbona-Göteborg: l'approccio concettuale e metodologico", in Bollettino della Società Geografica Italiana, serie 12, n.1, 2006, pp. 9-34

40. Prezioso M. (ed.), Competitiveness in Sustainability, Bologna, Patron, 2011

41. RENNER M., The Anatomy of Resource Wars, New York, World Watch Institute, Thomas Prugh Editor, 2002.

42. RichardS P., Fighting for the Rain Forest: War, Youth, \& Resources in Sierra Leone, Oxford, The International African Institute, 1996.

43. SAWYER A., Violent Conflicts and Governance Challenger in West Africa: The Case of the Mano River Basin Area, Workshop in Political and Policy Analysis, Indiana University, 2003.

44. SIERRA LEONE GOVERNMENT, New Education Policy for Sierra Leone, Ministry of Education, Youth and Sport, 1995.

45. TURCO A., "Centralità degli stati, marginalità dei popoli", in Nigrizia, gennaio 2004, pp. 30-32.

46. UNCTAD, State of South-South and triangular cooperation in the production, use and trade of sustainable biofuels, 2012

47. WhaITES A., States in Development: Understanding State-building, DFID Working Paper, DFID, London, 2008

48. ZaCK-WiLliams A. B., "Sierra Leone: the political economy of civil war, 1991-98", in Third World Quarterly, vol. 20, n. 1, 1999, pp. 143-162. 